\title{
Synthesis, characterization and antimicrobial activities of some metal(II) amino acids’ complexes
}

\author{
Temitayo Olufunmilayo Aiyelabola ${ }^{{ }^{*},}$, Isaac Ayoola Ojo ${ }^{1}$, Adeleke Clement Adebajo ${ }^{2}$, \\ Grace Olufunmilayo Ogunlusi ${ }^{1}$, Olayinka Oyetunji ${ }^{3}$, Ezekiel Olugbenga Akinkunmi ${ }^{4}$, \\ Adebowale Olusoji Adeoye ${ }^{5}$
}

\footnotetext{
${ }^{1}$ Department of Chemistry, Faculty of Science, Obafemi Awolowo University, Ile-Ife, Nigeria

${ }^{2}$ Department of Pharmacognosy, Faculty of Pharmacy, Obafemi Awolowo University, Ile-Ife, Nigeria

${ }^{3}$ Department of Chemistry, University of Botswana, Gaborone, Botswana

${ }^{4}$ Department of Pharmaceutics, Faculty of Pharmacy, Obafemi Awolowo University, Ile-Ife, Nigeria

${ }^{5}$ Adis Pharma Inc., 5238 Palmetto Place, Mississauga, ON L5M OC8, Canada

Email: "tt1haye@yahoo.com
}

Received 5 June 2012; revised 11 July 2012; accepted 22 July 2012

\begin{abstract}
Metal(II) coordination compounds of glycine and phenylalanine were synthesized and characterized using infrared and electronic spectroscopic, and magnetic susceptibility measurements. The complexes were tested for antimicrobial activity against Bacillus subtilis, Staphylococcus aureus, Methicillin Resistant Staphylococcus aureus (MRSA), Escherichia coli, Pseudomonas aeruginosa, Proteus vulgaris and Candida albicans. The stoichiometric reaction between the metal (II) ions and ligands in molar ratio M:L (1:3) [where $\mathrm{M}=\mathrm{Mn}, \mathrm{Co}, \mathrm{Ni}, \mathrm{Cu}$ and $\mathrm{Cd}$; $\mathrm{L}=$ glycine; phenylalanine] resulted in the formation of five-coordinate square pyramidal dinuclear geometry for both copper complexes and six-coordinate octahedral geometry for the other complexes. The spectroscopic and magnetic moment data suggested that the ligands coordinated via both their amino and carboxylate ion moieties. The complexes demonstrated better activities against one or more of the tested microbes than acriflavine, the standard drug used.
\end{abstract}

Keywords: Glycine; Phenylalanine; Coordination Compound; Antimicrobial; Chelation

\section{INTRODUCTION}

Antimicrobial resistance is fast becoming a global concern with rapid increase in multidrug-resistant bacteria and fungi $[1,2]$. This has mandated continued search for new antimicrobial compounds, including coordination complexes of biologically important molecules [3-5]. The increased lipophilic character of these coordinated compounds, with the resultant enhanced ability to permeate

${ }^{*}$ Corresponding author. the cell membrane of the microbes, have been suggested as reasons for their improved activity over their parent ligands [6,7]. Chelation, which has been reported to reduce the polarity of the metal ion by partial sharing of its positive charge with the donor group of ligands, also supports this theory $[8,9]$. Promising antimicrobial activities of some amino acids chelates have been reported, including those of histidine $[1,10]$, arginine and glutamic acid [11]. However, there is dearth of information on coordination compounds of phenylalanine. Coordination compounds of glycine $\left(\mathrm{L}_{1}\right)$ and phenylalanine $\left(\mathrm{L}_{2}\right)$ metalligand ratio 1:2 have been reported with marginal antimicrobial activities [12]. It was therefore suggested, based on the chelate theory $[6,9]$, that increasing the number of chelate rings may improve the antimicrobial activities of these complexes. Hence the objective of this work was to synthesize, characterize and determine the antimicrobial activities of coordination compounds of $\mathrm{L}_{1}$ and $\mathrm{L}_{2}$ with metal-ligand ratio $1: 3$. This was with a view of identifying lead metal(II) compounds for further studies in drug development against multidrug resistant bacteria and fungi.

\section{MATERIALS AND METHODS}

\subsection{General}

All reagents and solvents used were of analytical grade. Melting points (M.P) or temperature of decomposition (d) were measured using open capillary tubes on a Gallenkamp (variable heater) melting point apparatus. The UVVis spectra were obtained using a Genesis $10 \mathrm{UV}$-Vis spectrophotometer, solid reflectance. The magnetic susceptibility measurement for some of the complexes was obtained at room temperature using a MSB- AUTO (Sherwood scientific) Gouy balance. The infrared spectra $(\mathrm{KBr})$ were recorded on a Genesis II FT-IR spectrophotometer. 


\subsection{Synthesis of Complexes}

The coordination compounds were prepared according to a modification of previously reported method [13] by the addition of $0.01 \mathrm{M}$ of appropriate metal salt (1.62, 2.17, 2.43, 2.51 and $2.69 \mathrm{~g}$ for copper, cadmium, nickel, cobalt and manganese, respectively) to a solution of the ligand $\mathrm{L}_{1} 0.03 \mathrm{M}(2.29 \mathrm{~g})$ and $\mathrm{L}_{2} 0.03 \mathrm{M}(5.12 \mathrm{~g})$ dissolved with stirring in distilled water with the addition of $0.005 \mathrm{M}$ $\mathrm{Na}_{2} \mathrm{SO}_{4}(0.71 \mathrm{~g})$. The mixture was then heated on a water bath for $2 \mathrm{~h}$. An immediate precipitation was obtained for majority of the complexes, while some required further concentration and cooling. The products obtained were filtered, washed with methanol and dried in vacuo at $60^{\circ} \mathrm{C}$.

\subsection{Antimicrobial Activity Using Disc Diffusion Assay}

The antimicrobial properties of the complexes were obtained using an adaptation of the filter disc diffusion method [14]. The strains used were Escherichia coli NCTC 8196, Pseudomonas aeruginosa ATCC 19429, Staphylococcus aureus NCTC 6571, Proteus vulgaris NCIB, Bacillus subtilis NCIB 3610 and Methicillin resistant $S$. aureus (MRSA) clinical isolate for bacteria, and Candida albicans NCYC 6 for fungi while acriflavine was the standard drug.

\section{RESULTS AND DISCUSSION}

\subsection{Physico-Chemical Properties}

The colors, percentage yields and melting points (M.P) or temperature of decomposition (d) of the coordination compounds are presented in Table 1. The complexes showed a wide range of colors that were in agreement with those obtained for similar coordination compounds.

Some of the compounds decomposed before melting. All the complexes were sparingly soluble in general organic solvents and therefore efforts at growing their single crystals for X-ray structural studies were unsuccessful.

Table1. Some physical properties of the compounds.

\begin{tabular}{cccc}
\hline Compound & \% Yield & Colour & M.P./d. $\left({ }^{\circ} \mathrm{C}\right)$ \\
\hline $\mathrm{Na}\left[\mathrm{Co}\left(\mathrm{L}_{1}\right)_{3}\right]$ & 61.60 & Pink & $231-232$ \\
{$\left[\mathrm{Cu}\left(\mathrm{L}_{1}\right)_{2}\right]_{2}$} & 67.40 & Blue & $191-193$ \\
$\mathrm{Na}\left[\mathrm{Mn}\left(\mathrm{L}_{1}\right)_{3}\right]$ & 74.40 & White & $244-247$ \\
$\mathrm{Na}\left[\mathrm{Ni}\left(\mathrm{L}_{1}\right)_{3}\right]$ & 60.20 & Green & $226(\mathrm{~d})$ \\
$\mathrm{Na}\left[\mathrm{Cd}\left(\mathrm{L}_{1}\right)_{3}\right]$ & 59.70 & White & $198(\mathrm{~d})$ \\
$\mathrm{Na}\left[\mathrm{Co}\left(\mathrm{L}_{2}\right)_{3}\right]$ & 84.30 & Pink & $223(\mathrm{dt})$ \\
{$\left[\mathrm{Cu}\left(\mathrm{L}_{2}\right)_{2}\right]_{2}$} & 40.20 & Lilac & $198(\mathrm{~d})$ \\
$\mathrm{Na}\left[\mathrm{Mn}\left(\mathrm{L}_{2}\right)_{3}\right]$ & 69.60 & White & $229(\mathrm{~d})$ \\
$\mathrm{Na}\left[\mathrm{Ni}\left(\mathrm{L}_{2}\right)_{3}\right]$ & 72.80 & Pale green & $182(\mathrm{~d})$ \\
$\mathrm{Na}\left[\mathrm{Cd}\left(\mathrm{L}_{2}\right)_{3}\right]$ & 62.40 & White & $217(\mathrm{~d})$ \\
\hline
\end{tabular}

Keys: $\mathrm{L}_{1}$ : glycine; $\mathrm{L}_{2}$ : $d l$-phenylalanine; M.P.: Melting point; $d$.: temperature of decomposition.

\subsection{Electronic Spectra and Magnetic Moment}

The absorption bands of the ligands (Table 2) corresponded to the $\mathrm{n} \rightarrow \sigma^{*}, \mathrm{n} \rightarrow \pi^{*}$ and $\pi^{*} \rightarrow \pi^{*}$ transitions of $-\mathrm{NH}_{2}$ and $-\mathrm{COO}^{-}$, the major chromophores, and $-\mathrm{C}_{6} \mathrm{H}_{5}$. Shifts in these bands and the observed $d$ - $d$ transitions of the compounds, as presented in Table 2, indicated coordination.

\subsubsection{Glycinato Complexes}

The visible spectrum for this $\mathrm{Cu}$ (II) complex displayed bands at 620 and $632 \mathrm{~nm}$ assigned to ${ }^{2} \mathrm{~B}_{1 \mathrm{~g}} \rightarrow{ }^{2} \mathrm{~A}_{1 \mathrm{~g}}$ and ${ }^{2} \mathrm{~B}_{1 \mathrm{~g}} \rightarrow{ }^{2} \mathrm{E}_{1 \mathrm{~g}}$ transitions, ascribed to a square pyramidal geometry [15]. Its magnetic moment value of $1.53 \mathrm{~B}$. M, indicative of an antiferromagnetic spin-spin interaction through molecular association with possible $\mathrm{Cu}-\mathrm{Cu}$ interaction or dimerization, further confirmed this geometry $[8,15,16]$. Hence, these facts allowed the proposal of a dinuclear square pyramidal geometry for the complex. The spectrum for the $\mathrm{Cd}(\mathrm{II})$ complex exhibited bands at 772 and $829 \mathrm{~nm}$, indicative of charge transfer transition $(\mathrm{M} \rightarrow \mathrm{L})$ which is expected of $\mathrm{Cd}(\mathrm{II})$ with filled $4 d$ orbital in the ground state [16]. An octahedral geometry is however proposed for the Cd(II) complexes [16]. Nickel(II) complexes are known to exhibit complicated equilibrium between coordination numbers six (octahedral) and four (square planar/tetrahedral) [17]. The absorption bands at 505, 523 and $544 \mathrm{~nm}$ (Table 2) were consistent with a six-coordinate octahedral geometry and were assigned to ${ }^{3} \mathrm{~A}_{2 \mathrm{~g}}(\mathrm{~F}) \rightarrow{ }^{3} \mathrm{~T}_{1 \mathrm{~g}}(\mathrm{~F}),{ }^{3} \mathrm{~A}_{2 \mathrm{~g}}(\mathrm{~F}) \rightarrow{ }^{1} \mathrm{~T}_{\mathrm{g}}(\mathrm{F})$ and ${ }^{3} \mathrm{~A}_{2 \mathrm{~g}}(\mathrm{~F}) \rightarrow{ }^{1} \mathrm{E}_{\mathrm{g}}$ transitions, respectively [16]. Its magnetic moment of 1.28 B.M was lower than the spin only value of 2.83 B.M and suggested interconversion of stereochemistries or dimerization $[18,19]$. The Co(II) complex gave two well resolved absorption bands at 520 and $667 \mathrm{~nm}$, which were assigned to ${ }^{4} \mathrm{~T}_{1 \mathrm{~g}}(\mathrm{~F}) \rightarrow{ }^{4} \mathrm{~A}_{2 \mathrm{~g}}(\mathrm{~F})$ and ${ }^{4} \mathrm{~T}_{1 \mathrm{~g}}(\mathrm{~F}) \rightarrow{ }^{4} \mathrm{~T}_{1 \mathrm{~g}}(\mathrm{P})$ transitions, respectively consistent with a six coordinate octahedral

Table 2. Uv-Vis spectra bands (nm) of the compounds.

\begin{tabular}{cccccc}
\hline Compound & Band I & Band II & Band III & Band IV & $d$ - $d$ \\
\hline $\mathrm{L}_{1}$ & 199 & 211 & 244 & - & - \\
$\mathrm{L}_{2}$ & - & 217 & 232 & 268 & - \\
{$\left[\mathrm{Cu}\left(\mathrm{L}_{1}\right)_{2}\right]_{2}$} & - & 262 & - & - & 620,632 \\
$\mathrm{Na}\left[\mathrm{Cd}\left(\mathrm{L}_{1}\right)_{3}\right]$ & 226 & 265 & - & - & 772,829 \\
$\mathrm{Na}\left[\mathrm{Ni}\left(\mathrm{L}_{1}\right)_{3}\right]$ & 223 & 259 & - & - & $505,523,544$ \\
$\mathrm{Na}\left[\mathrm{Co}\left(\mathrm{L}_{1}\right)_{3}\right]$ & 220 & 226 & 256 & - & 520,667 \\
$\mathrm{Na}\left[\mathrm{Mn}\left(\mathrm{L}_{1}\right)_{3}\right]$ & - & 226 & - & - & $496,526,541$ \\
{$\left[\mathrm{Cu}\left(\mathrm{L}_{2}\right)_{2}\right]_{2}$} & 196 & 226 & 247 & 265 & $499 \mathrm{sh}, 538$ \\
$\mathrm{Na}\left[\mathrm{Cd}\left(\mathrm{L}_{2}\right)_{3}\right]$ & 205 & - & 238 & 265 & - \\
$\mathrm{Na}\left[\mathrm{Ni}\left(\mathrm{L}_{2}\right)_{3}\right]$ & 196 & 211 & 238 & 262 & $481 \mathrm{sh}, 496,526$ \\
$\mathrm{Na}\left[\mathrm{Co}\left(\mathrm{L}_{2}\right)_{3}\right]$ & 196 & 220 & 235 & 262 & 499,526 \\
$\mathrm{Na}\left[\mathrm{Mn}\left(\mathrm{L}_{2}\right)_{3}\right]$ & 199 & 217 & 238 & 265 & $433,496,523,538$ \\
\hline $\mathrm{Keys}$
\end{tabular}

Keys: sh: shoulder; $\mathrm{L}_{1}$ : glycine; $\mathrm{L}_{2}$ : $d l$-phenylalanine. 
geometry. Its magnetic moment of 5.20 B.M indicated a high spin $d^{7}$ system with three unpaired electrons, which corroborates the proposed octahedral geometry $[16,20,21]$. The Mn(II) complex exhibited low energy bands at 496, 526 and $541 \mathrm{~nm}$ that were consistent with a six coordinate octahedral geometry [16] and were assigned ${ }^{6} \mathrm{~A}_{1 \mathrm{~g}} \rightarrow{ }^{4} \mathrm{E}_{\mathrm{g}}$, ${ }^{6} \mathrm{~A}_{1 \mathrm{~g}} \rightarrow{ }^{4} \mathrm{~T}_{2 \mathrm{~g}}(\mathrm{G})$ and ${ }^{6} \mathrm{~A}_{1 \mathrm{~g}} \rightarrow{ }^{4} \mathrm{~T}_{\mathrm{lg}}(\mathrm{G})$ transitions, respectively. These transitions are a consequence of forbidden transitions to excited states of spin multiplicity other than six $[22,23]$.

\subsubsection{Phenylalanito Complexes}

For a perfect octahedral complex, transition spectrum for a $\mathrm{Cu}(\mathrm{II}), d^{9}$ complex is expected to show only a single band. However, the $\mathrm{Cu}(\mathrm{II})$ ion in an octahedral environment is subject to Jahn Teller distortion which lowers the symmetry of the molecule and reduces the degeneracy of the $\mathrm{e}_{\mathrm{g}}$ orbitals $[22,24]$. The $d-d$ transitions of the $\mathrm{Cu}(\mathrm{II})$ complex at 499sh and $538 \mathrm{~nm}$ (Table 2) were assigned to ${ }^{2} \mathrm{~B}_{1 \mathrm{~g}} \rightarrow{ }^{2} \mathrm{~A}_{1 \mathrm{~g}}$ and ${ }^{2} \mathrm{~B}_{1 \mathrm{~g}} \rightarrow{ }^{2} \mathrm{E}_{1 \mathrm{~g}}$ transitions, respectively. Its magnetic moment value of $1.73 \mathrm{~B}$. M suggested a dinuclear square pyramidal complex [16]. However, no distinct $d$ - $d$ transition band was observed with the cadmium-phenyalanito complex [22]. Bands at 496, 481sh and $526 \mathrm{~nm}$, assignable to the ${ }^{3} \mathrm{~A}_{2 \mathrm{~g}}(\mathrm{~F}) \rightarrow{ }^{3} \mathrm{~T}_{1 \mathrm{~g}}(\mathrm{~F}),{ }^{3} \mathrm{~A}_{2 \mathrm{~g}}(\mathrm{~F})$ $\rightarrow{ }^{1} \mathrm{~T}_{\mathrm{g}}(\mathrm{F})$ and ${ }^{3} \mathrm{~A}_{2 \mathrm{~g}}(\mathrm{~F}) \rightarrow{ }^{1} \mathrm{E}_{\mathrm{g}}$ transitions, respectively, observed with the $\mathrm{Ni}$ (II) complex, suggested a distorted octahedral geometry. The Co(II) complex showed $d-d$ transition bands at 499 and $526 \mathrm{~nm}$ and were assigned to ${ }^{4} \mathrm{~T}_{1 \mathrm{~g}}(\mathrm{~F}) \rightarrow{ }^{4} \mathrm{~T}_{1 \mathrm{~g}}(\mathrm{P})$ and ${ }^{4} \mathrm{~T}_{1 \mathrm{~g}}(\mathrm{~F}) \rightarrow{ }^{4} \mathrm{~A}_{2 \mathrm{~g}}(\mathrm{~F})$ transitions, respectively typical of an octahedral geometry [24]. Weak transition bands were observed for the manganese complex at 433, 496, 523 and $538 \mathrm{~nm}$ and attributed to ${ }^{6} \mathrm{~A}_{1 \mathrm{~g}} \rightarrow{ }^{4} \mathrm{~A}_{1 \mathrm{~g}}(\mathrm{G}),{ }^{6} \mathrm{~A}_{1 \mathrm{~g}} \rightarrow{ }^{4} \mathrm{E}_{\mathrm{g}}(\mathrm{G}),{ }^{6} \mathrm{~A}_{1 \mathrm{~g}} \rightarrow{ }^{4} \mathrm{~T}_{2 \mathrm{~g}}(\mathrm{G})$ and ${ }^{6} \mathrm{~A}_{1 \mathrm{~g}} \rightarrow$ ${ }^{4} \mathrm{~T}_{\mathrm{lg}}(\mathrm{G})$ transitions, respectively for a distorted octahedral geometry [16].

\subsection{Infrared Spectra}

The IR spectral assignment of the metal complexes was achieved by comparing their vibration frequencies with those of the free ligands (Table 3) and literature reports of similar compounds $[25,26]$.

\subsubsection{Glycinato-Complexes}

The N-H stretching vibration at $3119 \mathrm{~cm}^{-1}$ in glycine was shifted to higher frequencies with the complexes, suggesting that the coordination of the metal ions with the ligand was via the nitrogen atom [25-27]. This was corroborated by similar shifts in the weak C-N stretching frequency of the ligand at $1127 \mathrm{~cm}^{-1}$ to higher frequencies in the complexes [28].

Infrared studies on coordination compounds of amino acids have shown that the carboxylate ion is affected by coordination, making it a useful tool in structural studies [26]. Similarly, the asymmetric stretching vibration at $1615 \mathrm{~cm}^{-1}$ for the carboxylate ion was shifted to higher frequencies with the complexes, confirming coordination via this functional group. For the symmetric stretch, sharp extended bands were observed instead of distinct bands. This has been reported to be due to the zwitterionic nature of the ligand in the crystalline form [26]. Sharp extended bands at $\sim 3480-3620 \mathrm{~cm}^{-1}$ in the complexes indicated intermolecular hydrogen bonding between the uncoordinated oxygen atom of the carboxyl group and the amino group of neighboring molecule. Broad bands at $\sim 1340 \mathrm{~cm}^{-1}$ however confirmed the intramolecular hydrogen bonding [29]. New bands at $502-548$ and 621 - $695 \mathrm{~cm}^{-1}$ were assigned to (M-N) and M-O bond stretching band frequencies, respectively and served as further evidence of coordination via the nitrogen and oxygen atoms of the ligand.

\subsubsection{Phenylalanito-Complexes}

Bathochromic shifts of the phenylalanine N-H stretching frequency at $3454 \mathrm{~cm}^{-1}$ was observed in all the complexes, with the exception of the hypsochromic shift given by the cobalt complex (Table 3). This ligand had weak bands at 1626 and $1566 \mathrm{~cm}^{-1}$ that were assigned to the asymmentric and symmentric stretching bands of the carboxylate ion. They were weak as a result of the zwitterionic nature of the ligand $[26,30]$. In the complexes, the asymmetric stretching band experienced hypsochromic shifts. However, cadmium and copper complexes gave bathochromic shifts. It has been reported that for aromatic compounds, their N-H bending vibration bands often overlapped the aromatic $\mathrm{C}=\mathrm{C}$ absorption bands [30]. Consequently, a distinct $\mathrm{C}=\mathrm{C}$ band was not obtained for most of the complexes.

Table 3. Infrared frequencies $\left(\mathrm{cm}^{-1}\right)$ of the ligands and compounds.

\begin{tabular}{ccccccc}
\hline Compound & $\mathrm{NH}_{2}$ & ${ }_{\text {as }} \mathrm{COO}^{-}$ & ${ }_{\text {sy. }} \mathrm{COO}^{-}$ & $\mathrm{C}-\mathrm{N}$ & $\mathrm{M}-\mathrm{N}$ & $\mathrm{M}-\mathrm{O}$ \\
\hline $\mathrm{L}_{1}$ & $3119 \mathrm{br}$ & $1615 \mathrm{~s}$ & $1615 \mathrm{~s}$ & $1127 \mathrm{w}$ & - & - \\
$\mathrm{L}_{2}$ & $3454 \mathrm{br}$ & $1626 \mathrm{~m}$ & $1566 \mathrm{w}$ & $1070 \mathrm{~s}$ & - & - \\
{$\left[\mathrm{Cu}\left(\mathrm{L}_{1}\right)_{2}\right]_{2}$} & $3333 \mathrm{br}$ & $1632 \mathrm{br}$ & $1416 \mathrm{br}$ & $1210 \mathrm{~m}$ & $501 \mathrm{sh}$ & $695 \mathrm{sh}$ \\
$\mathrm{Na}\left[\mathrm{Cd}\left(\mathrm{L}_{1}\right)_{3}\right]$ & $3428 \mathrm{br}$ & $1714 \mathrm{~m}$ & $1462 \mathrm{~m}$ & $1226 \mathrm{~m}$ & $503 \mathrm{sh}$ & $668 \mathrm{~s}$ \\
$\mathrm{Na}\left[\mathrm{Ni}\left(\mathrm{L}_{1}\right)_{3}\right]$ & $3399 \mathrm{br}$ & $1634 \mathrm{~m}$ & $1422 \mathrm{w}$ & $1126 \mathrm{~m}$ & $501 \mathrm{~m}$ & $621 \mathrm{~m}$ \\
$\mathrm{Na}\left[\mathrm{Co}\left(\mathrm{L}_{1}\right)_{3}\right]$ & $3428 \mathrm{br}$ & $1621 \mathrm{~s}$ & $1454 \mathrm{~s}$ & $1236 \mathrm{~m}$ & $509 \mathrm{sh}$ & $672 \mathrm{~s}$ \\
$\mathrm{Na}\left[\mathrm{Mn}\left(\mathrm{L}_{1}\right)_{3}\right]$ & $3142 \mathrm{br}$ & $1624 \mathrm{~m}$ & $1464 \mathrm{~m}$ & $1206 \mathrm{~m}$ & $548 \mathrm{~s}$ & $631 \mathrm{w}$ \\
{$\left[\mathrm{Cu}\left(\mathrm{L}_{2}\right)_{2}\right]_{2}$} & $3289 \mathrm{~s}$ & $1608 \mathrm{w}$ & $1454 \mathrm{~s}$ & $1214 \mathrm{~s}$ & $518 \mathrm{~s}$ & $695 \mathrm{~s}$ \\
$\mathrm{Na}\left[\mathrm{Cd}\left(\mathrm{L}_{2}\right)_{3}\right]$ & $3424 \mathrm{br}$ & $1585 \mathrm{~s}$ & $1411 \mathrm{~s}-$ & $1208 \mathrm{~s}$ & $521 \mathrm{~s}$ & $699 \mathrm{~s}$ \\
$\mathrm{Na}\left[\mathrm{Ni}\left(\mathrm{L}_{2}\right)_{3}\right]$ & $3202 \mathrm{br}$ & $1687 \mathrm{~s}$ & - & $1264 \mathrm{~m}$ & $598 \mathrm{~s}$ & $655 \mathrm{~s}$ \\
$\mathrm{Na}\left[\mathrm{Co}\left(\mathrm{L}_{2}\right)_{3}\right]$ & $3467 \mathrm{br}$ & $1653 \mathrm{w}$ & - & $1208 \mathrm{~m}$ & $524 \mathrm{~m}$ & $675 \mathrm{~s}$ \\
$\mathrm{Na}\left[\mathrm{Mn}\left(\mathrm{L}_{2}\right)_{3}\right]$ & $3261 \mathrm{w}$ & $1656 \mathrm{w}$ & $1456 \mathrm{~s}$ & $1209 \mathrm{~m}$ & $520 \mathrm{~s}$ & $679 \mathrm{~m}$ \\
\hline $\mathrm{Keys}$ & & & & &
\end{tabular}

Keys: $\mathrm{L}_{1}$ : glycine; $\mathrm{L}_{2}$ : $d$-phenylalanine; w: weak; m: medium; s: strong; vs: very strong; br: broad; sh: sharp. 
Table 4. Zones of inhibition for the coordinated compounds $(20 \mathrm{mg} / \mathrm{ml})$.

\begin{tabular}{|c|c|c|c|c|c|c|c|}
\hline \multirow{3}{*}{ Compounds } & \multicolumn{7}{|c|}{ Zone of inhibition (mm) ${ }^{*}$} \\
\hline & \multicolumn{3}{|c|}{$\operatorname{Gram}(+)$} & \multicolumn{3}{|c|}{ Gram (-) } & \multirow{2}{*}{$\begin{array}{c}\text { Fungus } \\
\text { C. albicans }\end{array}$} \\
\hline & S. aureus & B. subtilis & MRSA & E. coli & Ps. aeruginosa & P. vulgaris & \\
\hline $\mathrm{Na}\left[\mathrm{Cd}\left(\mathrm{L}_{1}\right)_{3}\right]$ & $13.0 \pm 0.4$ & 6.0 & 6.0 & 6.0 & 6.0 & 6.0 & $20.0 \pm 0.4$ \\
\hline $\mathrm{Na}\left[\mathrm{Ni}\left(\mathrm{L}_{1}\right)_{3}\right]$ & 6.0 & 6.0 & 6.0 & 6.0 & 6.0 & $14.1 \pm 0.3$ & 6.0 \\
\hline $\mathrm{Na}\left[\mathrm{Co}\left(\mathrm{L}_{1}\right)_{3}\right]$ & $13.0 \pm 0.5$ & $13.1 \pm 1.0$ & $12.0 \pm 0.4$ & $9.0 \pm 0.3$ & $20.2 \pm 0.1$ & $9.0 \pm 0.2$ & 6.0 \\
\hline $\mathrm{Na}\left[\mathrm{Mn}\left(\mathrm{L}_{1}\right)_{3}\right]$ & $13.0 \pm 0.5$ & 6.0 & 6.0 & $13.1 \pm 0.2$ & 6.0 & 6.0 & 6.0 \\
\hline $\mathrm{Na}\left[\mathrm{Cd}\left(\mathrm{L}_{2}\right)_{3}\right]$ & $22.0 \pm 0.2$ & $18.0 \pm 0.2$ & $20.2 \pm 0.1$ & 6.0 & $8.0 \pm 0.3$ & $13.0 \pm 0.0$ & $44.0 \pm 0.4$ \\
\hline $\mathrm{Na}\left[\mathrm{Ni}\left(\mathrm{L}_{2}\right)_{3}\right]$ & 6.0 & 6.0 & 6.0 & 6.0 & 6.0 & 6.0 & $15.0 \pm 0.7$ \\
\hline $\mathrm{Na}\left[\mathrm{Co}\left(\mathrm{L}_{2}\right)_{3}\right]$ & 6.0 & $15.0 \pm 0.1$ & $15.0 \pm 0.0$ & 6.0 & $21.0 \pm 0.0$ & 6.0 & $15.0 \pm 0.0$ \\
\hline $\mathrm{Na}\left[\mathrm{Mn}\left(\mathrm{L}_{2}\right)_{3}\right]$ & $17.0 \pm 0.4$ & $8.0 \pm 0.5$ & $10.1 \pm 0.5$ & $8.1 \pm 0.6$ & $9.0 \pm 0.3$ & $8.0 \pm 0.8$ & 6.0 \\
\hline Acriflavine & $20.0 \pm 0.0$ & 6.0 & 6.0 & $20.0 \pm 0.0$ & 6.0 & $15.0 \pm 0.0$ & $19.0 \pm 6.0$ \\
\hline
\end{tabular}

* Zone size measured included the $6.0 \mathrm{~mm}$ size of the filter paper disc.

Broad bands at $3468-3823 \mathrm{~cm}^{-1}$ in the complexes indicated $\mathrm{N}-\mathrm{H} \cdot \cdots \mathrm{O}$ interaction [31]. In the low frequency region, the complexes had new bands at 598 - 518 and $699-655 \mathrm{~cm}^{-1}$, attributable to $(\mathrm{M}-\mathrm{N})$ and $(\mathrm{M}-\mathrm{O})$ stretching. This further supported that the coordination of the complexes was via the amino and carboxylate groups. Therefore, based on the above discussion of the results of the magnetic moment, electronic and infrared spectra, a dinuclear bipyramidal geometry is hereby proposed for the glycinato- and phenylalanito- $\mathrm{Cu}$ (II) complexes and octahedral geometry for the others. However, the octahedral geometry of the $\mathrm{Mn}(\mathrm{II})$ and $\mathrm{Ni}(\mathrm{II})$ complexes are suggested to be distorted.

\subsection{Antimicrobial Activity}

The antimicrobial activities of the compounds are presented in Table 4. The results obtained indicated that glycine, and both copper complexes were inactive to all the tested organisms while phenyalanine and $\mathrm{Na}\left[\mathrm{Ni}\left(\mathrm{L}_{2}\right)_{3}\right]$ had marginal (zone of inhibition $14.0 \mathrm{~mm}$ ) antifungal activity (Table 4). The activity of acriflavine against E. coli was significantly $(\mathrm{p}<0.05)$ higher than all the coordinated compounds while the standard drug was inactive against some of the tested bacteria. The antimicrobial activities of some of the complexes against B. subtilis, MRSA, Ps. aeruginosa and $C$. albicans were significantly higher than the standard drug (Table 4), indicating their potentials as antimicrobial agents against these microbes. The compound with the highest antimicrobial spectrum was $\mathrm{Na}\left[\mathrm{Cd}\left(\mathrm{L}_{2}\right)_{3}\right]$ followed by $\mathrm{Na}\left[\mathrm{Co}\left(\mathrm{L}_{1}\right)_{3}\right]$ and $\mathrm{Na}\left[\mathrm{Co}\left(\mathrm{L}_{2}\right)_{3}\right]$. Also, $\mathrm{Na}\left[\mathrm{Cd}\left(\mathrm{L}_{2}\right)_{3}\right]$ had the greatest activity against $C$. albicans as well as against the Gram +ve bacteria tested. $\mathrm{Na}\left[\mathrm{Co}\left(\mathrm{L}_{1}\right)_{3}\right]$ and $\mathrm{Na}\left[\mathrm{Co}\left(\mathrm{L}_{2}\right)_{3}\right]$ demonstrated the highest activity against Ps. aeruginosa, the most susceptible Gram -ve bacterium tested. This may confirm the antimicrobial property of cobalt [6]. However, higher activities given by these cobalt complexes than those of copper, contrary to the antimicrobial potencies of their metals
[4,32-35], may indicate the influence of the proposed dinuclear structure.

Similar to previous reports $[4,36]$, the complexes showed better activity against the Gram +ve bacteria, with the exception of $\mathrm{Na}\left[\mathrm{Cd}\left(\mathrm{L}_{2}\right)_{3}\right]$ and $\mathrm{Na}\left[\mathrm{Ni}\left(\mathrm{L}_{1}\right)_{3}\right]$ against $P$. vulgaris, $\mathrm{Na}\left[\mathrm{Co}\left(\mathrm{L}_{1}\right)_{3}\right], \mathrm{Na}\left[\mathrm{Mn}\left(\mathrm{L}_{1}\right)_{3}\right]$ against E.coli and $\mathrm{Na}[\mathrm{Co}$ $\left(\mathrm{L}_{2}\right)_{3}$ ] against Ps. aeruginosa (Table 4). This indicates their usefulness as broad spectrum antibacterial agents. The four-coordinate $\mathrm{Cu}\left(\mathrm{L}_{1}\right)_{2}$ and $\mathrm{Cu}\left(\mathrm{L}_{2}\right)_{2}$ had better activities against $E$. coli and $S$. aureus [12] than the present dinuclear $\mathrm{Cu}(\mathrm{II})$ complexes. The activities of $\mathrm{Ni}\left(\mathrm{L}_{1}\right)_{2}$, $\mathrm{Co}\left(\mathrm{L}_{1}\right)_{2}$ and $\mathrm{Mn}\left(\mathrm{L}_{1}\right)_{2}$ against $C$. albicans [12] were also better than the current six-coordinate complexes while that of $\mathrm{Mn}\left(\mathrm{L}_{1}\right)_{2}$ against $B$. subtilis [12] was significantly higher. Apart from these exceptions, the six-coordinate complexes (Table 4) demonstrated better activities than their corresponding four-coordinate complexes [12]. This enhancement of activity suggests that chelation moderately increased the lipophilic character of the compounds and subsequently their permeation through the lipoid layer of the microbe's cell membrane [37-40].

\section{CONCLUSION}

The results of this study indicated that $\mathrm{L}_{1}$ and $\mathrm{L}_{2}$ coordinated in a bi-dentate manner using both nitrogen and oxygen atoms. This assignment is corroborated by spectral and magnetic moment data. The compounds exhibited a broad spectrum of activity against the tested microbes. Some of the compounds however exhibited increased antimicrobial activity with increased number of chelate rings. Hence, chelation may serve as a useful tool in the design of potential antimicrobial agents.

\section{REFERENCES}

[1] Saha, S., Dhanasekaran, D., Chandraleka, S., Thajuddin, N. and Panneerselvam, A. (2010) Synthesis, characterization and antimicrobial activity of cobalt metal complexes 
against drug resistant bacterial and fungal pathogens. Advances in Biological Research, 4, 224-229.

[2] Mulligan, M.E. and Murray-Leisure, K. (1993) Methicillin-resistant Staphylococcus aureus: A consensus review of the microbiology, pathogenesis, and epidemiology with implications for prevention and management. American Journal of Medicine, 94, 313-328. doi:10.1016/0002-9343(93)90063-U

[3] Farrell, N. (2003) Metal complexes as drugs and chemotherapeutic agents. Comprehensive Coordination Chemistry, 9, 809-840.

[4] Faúndez, G., Troncoso, M., Navarrete, P. and Figueroa, G. (2004) Antimicrobial activity of copper surfaces against suspensions of Salmonella enterica and Campylobacter jejuni. Bio-Medical Central Microbiology, 4, 19-26.

[5] Johari, R., Kumar, G., Kumar, D. and Singh, S. (2009) Synthesis and antibacterial activity of M(II) schiff-base complex. Journal of the Indian Chemistry Council, 26, 23-27.

[6] Chang, E., Simmers, C. and Knight, A., (2010) Cobalt complexes as antiviral and antibacterial agents. Pharmaceuticals, 3, 1711-1728. doi:10.3390/ph3061711

[7] Husseiny, A.F., Aazam, E.S. and Al Shebary, J. (2008) Synthesis, characterization and antibacterial activity of schiff-base ligand incorporating coumarin moiety and it metal complexes. Inorganic Chemistry, 3, 64-68.

[8] Chohan, Z.H., Arif, M., Akhtar, M.A. and Supuran, C.T. (2006) Metal based antibacterial and antifungal agents: Synthesis, characterization and in-vitro biological evaluation of $\mathrm{Co}(\mathrm{II}), \mathrm{Cu}(\mathrm{II}), \mathrm{Ni}(\mathrm{II})$, and $\mathrm{Zn}$ (II) complexes with amino acid-derived compounds. Bioinorganic Chemistry and Applications, 2006, 1-11.

doi:10.1155/BCA/2006/83131

[9] Rehman, S., Ikram, M., Rehman, S., Faiz, A. and Shahnawaz, A. (2010) Synthesis, characterization and antimicrobial studies of transition metal complexes of imidazole derivative. Bulletin of Chemical Society of Ethiopia, 24, 201-207.

[10] Nomiya, K., Takahashi, S., Noguchi, R., Nemoto, S., Takayama, T. and Oda, M. (2000) Synthesis and characterization of water-soluble silver(I) complexes with Lhistidine $\left(\mathrm{H}_{2}\right.$ his $)$ and $(S)$-(-)-2-pyrrolidone-5-carboxylic acid $\left(\mathrm{H}_{2}\right.$ pyrrld $)$ showing a wide spectrum of effective antibacterial and antifungal activities. Crystal structures of chiral helical polymers $[\mathrm{Ag}(\mathrm{Hhis})]_{n}$ and $\left\{[\mathrm{Ag}(\mathrm{Hpyrrld})]_{2}\right\}_{n}$ in the solid state. Inorganic Chemistry, 39, 3301-3311. doi:10.1021/ic9905260

[11] Legler, A., Kazachenko, A., Kazbanov, V. and Per' yanova, O. (2001) Synthesis and antimicrobial activity of silver complexes with arginine and glutamic acid. Pharmaceutical Chemistry, 35, 35-36. doi:10.1023/A:1014098810078

[12] Aiyelabola, T., Ojo, I. and Akinkunmi, O. (2012) Structural and antimicrobial studies of coordination compounds of phenylalanine and glycine. International Journal of Chemistry, 4, 49-59. doi:10.5539/ijc.v4n2p49

[13] Nomiya, K. and Yokoyama, H. (2002) Synthesis, crystal structures anti antimicrobial activities of polymeric sil-
ver(I) complexes with three amino-acids [aspartic acid ( $\mathrm{H}_{2} \mathrm{asp}$ ), glycine (Hgly) and asparagines (Hasn)]. Journal of Chemical Society, Dalton Transaction, 2483-2490. doi: $10.1039 / \mathrm{b} 200684 \mathrm{~g}$

[14] Murray, P.R., Baroon, E.J., Pfaller, M.A., Tenover, F.C. and Yolke, R.H. (1995) Manual of clinical microbiology. 6th Edition, American Society for Microbiology, Washington DC, 56-77.

[15] Youssef, N.S. and Hegab, K.H. (2005) Synthesis and Characterization of Some Transition Metal complexes of thiosemicarbazones derived from 2-acetylpyrrole and 2acetylfuran. Synthesis and Reactivity in Inorganic and Metal-Organic Chemistry, 35, 391-399. doi:10.1081/SIM-200059215

[16] Greenwood, N.N. and Earnshaw, A. (1997) Coordination compounds. Butterworth-Heinemann, Hong Kong, 10601090.

[17] Osowole, A. (2011) Synthesis, characterization and magnetic and thermal studies on some metal(II) thiophenyl schiff base complexes. International Journal of Inorganic Chemistry, 2011, 1-7. doi:10.1155/2011/650186

[18] Dawood, Z.F., Mohammed, T.J. and Sharif, M.R. (2009) New nickel(II) complexes with benzilbis (semicarbazone) and dithiocarbamate ligands. Iraqi Journal of Veterinary Sciences, 23, 135-141.

[19] Osowole, A.A., Woods, J.A.O. and Odunola, O.A. (2000). Synthesis and characterization of synthesis and physico-chemical properties of some copper(ii) $\beta$-ketoamines and their adducts with 2,2-bipyridine and 1,10-phenanthroline.some nickel(II) $\beta$-ketoamines and their adducts with 2,2-bipyridine and 1,10-phenanthroline. Synthesis and Reactivity of Inorganic and Metal Organic Chemistry, 32, 783-799. doi:10.1081/SIM-120004446

[20] Ballhausen, C.J. (1962) An introduction to ligand field theory. McGraw Hill, New York.

[21] Sathisha, M., Revankar, V. and Pai, K. (2008) Synthesis, structure, electrochemistry and spectral characterization of bis-isatin thiocarbohydrazone metal complexes and their antitumor activity against Ehrlich ascites carcinoma in Swiss albino mice. Metal Based Drugs, 2008, 362-375.

[22] Miessler, G.L. and Tarr, D.A. (1999) Coordination compounds. Pearson Prentice Hall, New York, 315-316.

[23] Cotton, F.A. and Wilkinson, G. (1981) Advanced inorganic chemistry. John Wiley and Sons, New York, 628816.

[24] Lever, A.B.P. (1986) Inorganic electronic spectroscopy. Elsevier, London, 481-579.

[25] Fessenden, R.J. and Fessenden, J.S. (1990) Organic chemistry. Harness and Nabie Inc., 1048.

[26] Nakamoto, K. (2009) Complexes of amino acids. In: K. Nakamoto, Ed., Infrared and Raman Spectra of Inorganic and Coordination Compounds, Wiley Interscience, New York, 66-74.

[27] Elzahany, E.A., Hegab, K.H., Safaa, K.H. and Youssef, N.S. (2008) Synthesis, characterization and biological activity of some transition metal complexes with Schiff Bases derived from 2-formylindole, salicyladehyde and 
$\mathrm{N}$-amino rhodanine. Australian Journal of Basic and Applied Sciences, 2, 210-220.

[28] Fahmideh, S., Lotf, A.S. and Shahriar, G. (2010) Synthesis, characterization and anti-tumour activity of $\mathrm{Fe}(\mathrm{III})$ schiff base complexes with unsymmetric tetradentate ligands. Bulletin of Chemical Society of Ethiopia, 24, 193199.

[29] Konstantinovic, S., Radovanovic, C., Cakic, Z. and Vasic, V. (2003) Synthesis and characterization of Cd(II), Ni(II), $\mathrm{Cu}(\mathrm{II})$ and $\mathrm{Zn}(\mathrm{II})$ complexes with 3-salicylidenehydrazono-2-indolinone. Journal of the Serbian Chemical Society, 68, 641-647. doi:10.2298/JSC0309641K

[30] Pavia, D., Lampman G. and Kriz G. (2001) Introduction to spectroscopy, a guide for students of organic chemistry. Brooks and Cole, Florence.

[31] Saunders, D.L. (2009) Isolation of lead-amino acid and mercury-amino acid complexes with characterization in the solid state, the solution state, and the gas phase. Ph.D. Thesis, Department of Chemistry, Dalhousie University, Halifax.

[32] Ibrahim, M., Wang, F., Lou, M., Xie, G., Li, B., Bo, Z., Zhang, G., Liu, H. and Wareth, A. (2011) Copper as an antibacterial agent for human pathogenic multidrug resistant Burkholderia cepacia complex bacteria. Journal of Bioscience and Bioengineering, 112, 570-576. doi:10.1016/j.jbiosc.2011.08.017

[33] Abushelaibi, A. (2005) antimicrobial effects of copper and brass ions on the growth of Listeria Monocytogenes at different temperatures, $\mathrm{pH}$ and nutrients. Ph.D. Thesis, Department of Food Science, Agricultural and Mechanical College, Louisiana State University, Louisiana.

[34] Centre for Applied Microbiology and Research (2000)
http://www.copper.org/about/pressreleases/2000/Demons tratePotential.html

[35] Copper Development Centre (2004) Antimicrobial: Copper.

http://www.copper.org.sg/publications/cca/0309/pg06 ja pan_research.html

[36] Kabbani, A.T., Hammud, H.H. and Ghannoum, A.M. (2007) Preparation and antibacterial activity of copper and cobalt complexes of 4-chloro-3-nitrobenzoate with a nitrogen donor ligand. Pharmaceutical Chemistry Bulletin, 55, 446-450. doi:10.1248/cpb.55.446

[37] Chohan, Z.H., Scozzafava, A. and Supuran, C.T. (2006) Synthesis of biologically active $\mathrm{Co}(\mathrm{II}), \mathrm{Cu}(\mathrm{II}), \mathrm{Ni}(\mathrm{II})$ and $\mathrm{Zn}$ (II) complexes of symmetrically 1,1'-disubstituted ferrocene derived compounds. Synthesis and Reactivity in Inorganic and Metal-Organic Chemistry, 33, 241-257. doi:10.1081/SIM-120017783

[38] Chohan, Z.H., Farooq, M.A., Scozzafava, A. and Supuran, C.T. (2002) Antibacterial schiff bases of oxalyl-hydrazine; diamide incorporating pyrrolyl and salicylyl moieties and of their zinc(II). Journal of Enzyme Inhibition and $\mathrm{Me}$ dicinal Chemistry, 17, 1-7. doi:10.1080/14756360290005598

[39] Garba, S. and Salihu, L. (2011) Antibacterial activities of 2-O-butyl-1-O-(2'-ethylhexyl) benzene-1,8-dicarboxylate and 1-phenyl-1,4-pentanedione isolated from Vitellaria paradoxa root bark. Asian Journal of Scientific Research, 4, 149-157. doi:10.3923/ajsr.2011.149.157

[40] Stanila, A., Marcu, A., Rusu, D., Rusu, M. and David, L. (2007) Spectroscopic studies of some copper (II) complexes with amino acids. Journal of Molecular Structure, 834-836, 364-368. doi:10.1016/j.molstruc.2006.11.048 